\title{
除草剤アロキシジムおよびセトキシジムの開発
}

\author{
石川尚雄, 岩滝 功, 佐脇幹夫* \\ 日本曹達株式会社小田原研究所 \\ *日本曹達株式会社生産技術研究所
}

\section{The Development of Two Herbicides, Alloxydim-sodium and Sethoxydim}

\author{
Hisao Ishikawa, Isao Iwataki and Mikio Sawaki* \\ Odawara Research Center, Nippon Soda Co., Ltd., \\ Takada, Odawara 250-02, Japan \\ *Takaoka Laboratory Takaoka Works, Nippon Soda Co., Ltd., \\ Mukainohon-machi, Takaoka 933, Japan
}

Both of alloxydim-sodium [Sodium salt of methyl 3-(1-allyloxyaminobutylidene)-6,6dimethyl-2,4-dioxocyclohexylcarboxylate] and sethoxydim $( \pm)-2-(1-$ ethoxyiminobutyl)-5-[2(ethylthio)propyl]-3-hydroxycyclohex-2-enone are postemergence herbicides that provide excellent control of a wide range of grass weeds. The studies on them were started from the discovery of a new compound among the benzoxamate (miticide) derivatives having a weak herbicidal activity on grass weed. As a result of the research on the derivatives of various heterocyclic compounds such as pyrans, dimedones and barbituric acids, the dimedone derivatives were found to show the highest activity in postemergence treatment, and an alkoxyamino alkylidene moiety was indispensable on dimedone ring. Thus we selected out a compound from the dimedone derivatives and commercialized it in formulation of alloxydimsodium. It showed excellent activity on annual grasses at $1 \mathrm{~kg} / \mathrm{ha}$ approximately. However, the dosage more than $4 \mathrm{~kg} / \mathrm{ha}$ was needed to control perennial grasses completely, especially johnsongrass (Sorghum halepense). Further investigation was carried out to find out more potent herbicide. Before long, we found that some compounds with additional substituent, sulfur-containing alkyl group at 5-position of 1,3-dioxocyclohexane ring instead of the gemdimethyl of dimedone, gave excellent control of annual and perennial grasses. A lot of the cyclohexane derivatives with a sulfur-containing alkyl side chain were synthesized and screened. As the result, we picked out a compound (sethoxydim) providing always high activity in field trials. Sethoxydim effectively controlled annual grasses and johnsongrass at $0.2-0.4 \mathrm{~kg} / \mathrm{ha}$ and $0.5 \mathrm{~kg} / \mathrm{ha}$ respectively, and showed excellent selectivity in numerous dicotyledonous crops. Some simulated rainfall and partial droplet application studies revealed that sethoxydim appeared to be readily absorbed and translocated in the plants. Two gramineous species, Festuca rubra and $F$. myuros were resistant as high as broadleaf weeds, while $F$. arundinacea and $F$. pratensis were susceptible. This difference in susceptibility could not explain by absorption, translocation and metabolism. Microscopic studies revealed that sethoxydim attacked the meristematic regions and inhibited the cell divisions, resulting in the occurrence of herbicidal action. 


\section{は じめに}

除草郕の開発はいくつかの優れた畑作用除草剂を生み 出してきた，そのなかには雑草の発芽前に用いられる土

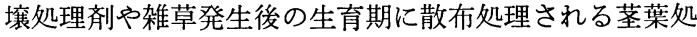
理剂等があげられる。土壤処理剤のなかには広葉，イネ 科雑草に対しともに高い活性を示すむの，あるいはその ぞちらかに強い作用を示薬凨がいくつか知られてい る. 荃葉処理郕では広葉雑草に高い活性を示寸薬剤は多 く知られているが，イネ科雑草に高い活性を示す除草郕 はほとんぞなかった. 今からさかのぼること十数年前, 欧州ではイネ科雑草が年々増加の傾向にあることが報告 され ${ }^{123)}$, イネ科雑草の防除が大きな問題となりつつあっ た.

筆者らはイネ科雑草の防除に高い関心を持ちつつイネ 科雑草に作用を示す化合物の探索を続けていたところ， 殺ダニ剂のベンゾメート（エチルO-ベンゾイル-3-クロ ル-2,6-ジメトキシベンゾヒドロキシメート)の関連化合 物のなかにイネ科雑草に作用を示す化合物を見いだし た. 各種のへテロ環,置換基を導入し，その活性について 検討した結果, 茎葉散布処理でイネ科雑草にのみ特異的 に高い殺草作用を示すという従来の除草剤にない構造と 活性を有する化合物を多数見いだし,活性,合成，製郕面 等からアロキシジム (alloxydim-sodium) とセトキシジ ム (sethoxydim) を選抜した。アロキシジムは本邦をは ビめとし欧州，南米等 27 力国でテンサイ，ナタネ，フ マ, バレイショ等のスズメノテッポウ，野性エンバク等 の一年生イネ科雑草の防除を主体に, 生育期全面茎葉処 理剂として使用されている。 セトキシジムは打もに米 国，カナダを中心に 22 力国で大豆，棉，タマネギ畑等 の一年生雑草打よびセイバンモロコシ等の多年生イネ科 雑草の防除剂として広く用いられている。また広葉雑草 も同時に防除する場合は，広葉雑草に活性を示す除草剂 と混合して用いられている.

本報では 2 凪の開発に至るまでの探索研究の経緯の一 部とセトキシジムの合成法，作用特性等を中心にその概 要を述べる。

\section{合成化合物の構造と生物活性}

十数年前, ベンゾメートの活性に大きく関与している と考えられたエチルヒドロキシメート部分に着目し，種 種の生理活性が知られている天然物のクマリン ${ }^{4,5)}$ 等の 骨格を参考にしながら合成した数多くの化合物中に土壌 処理試験でイネ科雑草に活性を示す化合物を見いだし た. 活性的には室内レベルで $5 \mathrm{~kg} / \mathrm{ha}$ 以上の薬量が必要
Table 1 Herbicidal activity of pyrone derivatives on Digitaria adscendens in pre-emergence treatment.

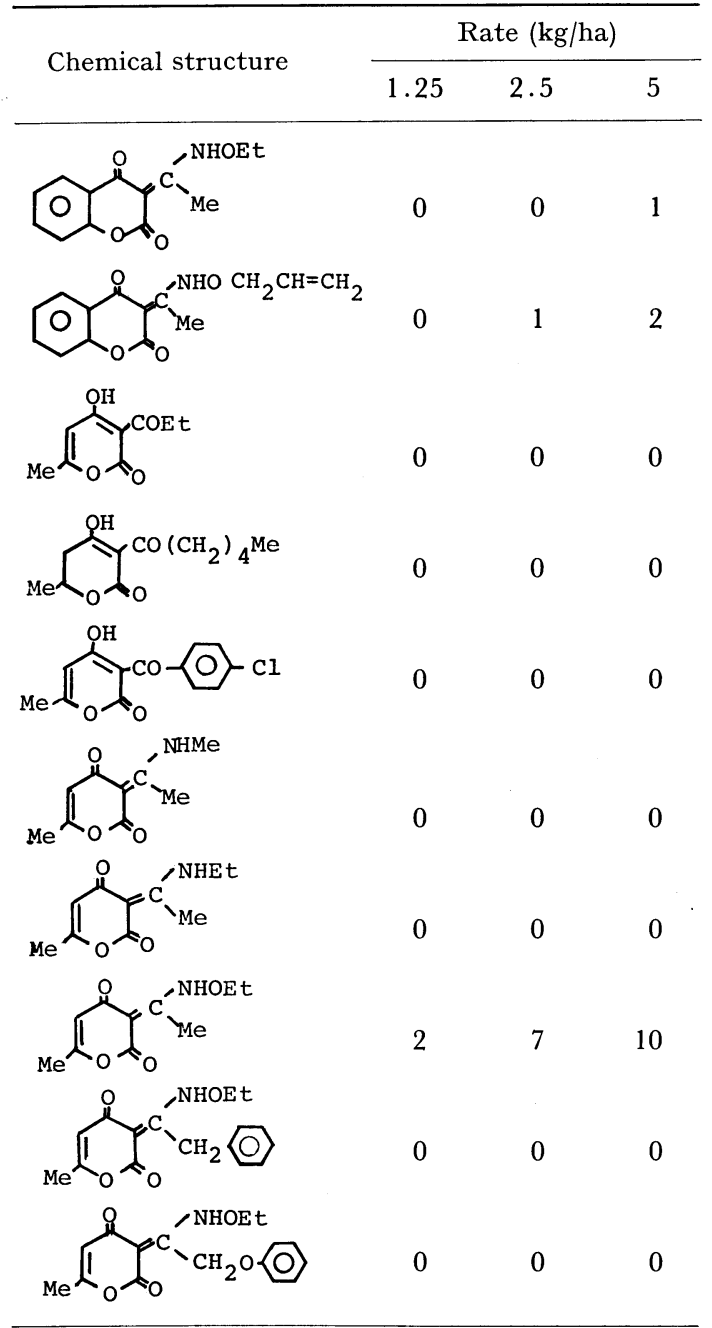

0 : no effect, 10: total control.

であり，除草剤としてはまったく不十分な効力であった が，待ち望んでいたイネ科雑草に作用を示す化合物を見 いだした。とくにピロン誘導体が高い活性を示し，しか も側鎖にアルコキシアミノ基を有する場合に作用を示し た (Table 1)。そこで多数のピロン誘導体を合成し，側 鎖について検討した結果， $\mathrm{R}_{2}$ (Table 2) 部分にエチル基 かプロピル基を有する場合に最も高い活性が得られ，水 素, メチル基またはブチル基等では活性は劣り, 炭素数 が 2 〜 のときに活性のピークがあることがわかった. 一方，6位の $\mathrm{R}_{1}$ もこれと似た傾向を示し，炭素数 2 4 付近で高い活性を示した. しかしながらいずれの化合 
Table 2 Herbicidal activity of pyrone derivatives on Digitaria adscendens.<smiles>[R1]C1=CC(=O)C(C([R2])NCC)C(=O)O1</smiles>

\begin{tabular}{|c|c|c|c|c|c|}
\hline \multirow{2}{*}{$\mathrm{R}_{1}$} & \multirow{2}{*}{$\mathrm{R}_{2}$} & \multicolumn{2}{|c|}{ Pre-emergence } & \multicolumn{2}{|c|}{ Post-emergence } \\
\hline & & $1.25^{\mathrm{a})}$ & 2.5 & $1.25^{\mathrm{a})}$ & 2.5 \\
\hline $\mathrm{Me}$ & $\mathrm{H}$ & 0 & 0 & 0 & 0 \\
\hline $\mathrm{Me}$ & $\mathrm{Me}$ & 8 & 3 & 1 & 5 \\
\hline $\mathrm{Me}$ & Et & 10 & 10 & 2 & 6 \\
\hline $\mathrm{Me}$ & $\mathrm{Pr}$ & 10 & 10 & 2 & 8 \\
\hline $\mathrm{Me}$ & $\mathrm{Bu}$ & 0 & 4 & 0 & 0 \\
\hline $\mathrm{Me}$ & $\left(\mathrm{CH}_{2}\right)_{4} \mathrm{Me}$ & 0 & 0 & 0 & 0 \\
\hline $\mathrm{Me}$ & $\mathrm{CH}_{2}-\langle\overline{\mathrm{O}}\rangle$ & 0 & 0 & 0 & 0 \\
\hline $\mathrm{Me}$ & $\mathrm{CH}_{2} \mathrm{O}-\langle\overline{\underline{O}}\rangle$ & 0 & 0 & 0 & 0 \\
\hline $\mathrm{Et}$ & Et & 10 & 10 & 7 & 9 \\
\hline $\operatorname{Pr}$ & Et & 10 & 10 & 5 & 7 \\
\hline$i$-Bu & Et & 10 & 10 & 3 & 8 \\
\hline$\langle\underline{\bar{O}}\rangle$ & Et & 0 & 0 & 0 & 0 \\
\hline
\end{tabular}

a) application rate $(\mathrm{kg} / \mathrm{ha})$.

0 : no effect, 10: total control.

物も茎葉処理試験における活性は低く, 当初の目的であ る茎葉処理型の活性を示す化合物は得られなかった。そ こでアルコキシアミノ基部分を残し，ピロン環に類縁の ヘテロ環の導入を試みた結果 (Table 3), 荠葉処理試験 でジメドン誘導体中にわずかながら高い活性を示す化合 物が見いだされた。 そこでこの誘導体のアルコキシアミ ン, アルキリデン部分および 4 位に置換基の導入を図っ た結果 (Table 4), $\mathrm{R}_{1}$ が無置換の時はピロン環の場合と 同様に活性はなく，一般にアルキルの長さが炭素数 3 の 時に最も高い活性を示し，それ以下あるいは以上の長さ の時に活性は低下した， $\mathrm{R}_{2}$ はアリル基またはプロパル ギル基のように不飽和の炭素数 3 の場合に最も高い活 性を示した. アルコキシアミノ基に代わってアルキルア ミノ基を導入した場合, 活性はまったくなく, ジメドン 誘導体においても分子内にアルコキシアミノ基の存在が 活性の発現に必須であることがわかった， $\mathrm{R}_{4}$ における アルキル基, アルコキシカルボニル基等の有無を検討し た結果, 無置換の場合とメトキシカルボニル基の場合に 強い効力を示し, その他の場合は劣った.

以上から菱葉処理による高い殺草活性を示す化学構造 部分の最適条件が判明し, 工業的製造法の検討等からア ロキシジムを選抜し，ナトリウム塩として安定性を強化 した. アロキシジムは $0.75 \sim 1 \mathrm{~kg} / \mathrm{ha}$ で一年生イネ科雑 草に卓効を示し, しかもその薬量では広葉の作物にまっ
たく薬害がなく，作物の生育期に全面散布し作物畑中の イネ科雑草を防除することができる。しかしながらアロ キシジムは米国等で重要害草といわれているセイバンモ ロコシに効力が不十分であり，その防除には $4 \mathrm{~kg} / \mathrm{ha}$ 以 上を必要とし，経済的な面等からその使用は困難であっ た。 そこで筆者らは，さらに多年生のイネ科雑草にも使 用できる除草凨の開発を試みた。

ジメドン誘導体の置換基検討箇所として残されていた 5 位に各種の置換基を導入したところ (Table 5), 環状 アルキル基で比較的高い活性を認めたが，セイバンモロ コシに不十分な活性であった。イオウ原子を含んだアル キル基置換体には顕著な高い活性を見いだした. 酸素原 子の場合には活性の向上は認められなかったことなどか らイオウを含むアルキル基の分子内存在が，一年生雑草 と同時に多年生雑草のセイバンモロコシにも高い活性を 示す重要な置換基と考えられたのでイオウを含む各種の アルキル基の導入を試みた結果 (Table 6), ほとんどの 化合物が高い活性を示した. しかし 5 位以外への導入は 活性を大きく低下させた (No. 27-29). イオウ原子にお ける酸化誘導体 (21-26) は, 酸化が進むにつれて活性は 低下寸る傾向にあった，とくに優れた化合物について低 薬量でアロキシジムとの活性を比較した結果, 冬雑草の スズメノテッポウ, 野性エンバクには約 4 倍の効力差が あり，セイバンモロコシにはさらに大きな効力差が認め 
Table 3 Herbicidal activities ${ }^{\mathrm{a}}$ ) of various cyclic 1,3-dione derivatives.

Chemical structure

$\mathrm{X}$<smiles>[X]/C(=C\c1c(O)n([Y4])c(=O)n(C)c1=O)C(=[X])CC</smiles><smiles>[Y16]N1SN(S(=O)(=O)[O-])C(O)=C(C(CC)=NOCC)C1=O</smiles><smiles>CCON=C(CC)C1=C(O)OC(C)(C)OC1=O</smiles><smiles>CCO/N=C(\CC)c1c(O)cc(CC)oc1=O</smiles><smiles>CCO/N=C(\CC)C1=C(O)CC(CC)OC1=O</smiles><smiles>CCO/N=C(\CC)C1=C(O)CSC(C)C1=O</smiles><smiles>CCO/N=C/C1=C(O)CC(C)(C)CC1=O</smiles><smiles>CCON=C(CC)C1=C(O)CC(C)(C)CC1=O</smiles><smiles>CCO/N=C(/C1=C(O)CC(C)(C)CC1=O)c1ccccc1</smiles><smiles>[X]C(=C)C1=C(O)CC(C)(C)CC1=O</smiles>

$\mathrm{O}$

$\mathrm{N}-\mathrm{Me}$
N-OEt

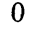

2

3

3

1

$0.25 \quad 1.0$

0

0

0

4

10

8

10

$0.25 \quad 1.0^{\mathrm{b}}$

$1.0^{\mathrm{b})}$

a) post-emergence treatment, 2 weeks after application.

b) application rate $(\mathrm{kg} / \mathrm{ha})$.

0 : no effect, 10: total control.

$\begin{array}{lrrrr}\text { O } & 0 & 0 & 0 & 0 \\ \text { N-Me } & 0 & 3 & 0 & 3 \\ \text { N-O allyl } & 9 & 10 & 10 & 10\end{array}$


Table 4 Herbicidal activities of cyclohexanedione derivatives on grasses in post-emergence treatment. ${ }^{6}$

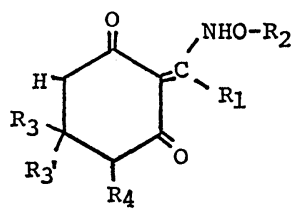

\begin{tabular}{|c|c|c|c|c|c|c|c|c|c|c|}
\hline \multirow[t]{2}{*}{$\mathrm{R}_{1}$} & \multirow[t]{2}{*}{$\mathrm{R}_{2}$} & \multirow[t]{2}{*}{$\mathrm{R}_{3}$} & \multirow{2}{*}{$\mathrm{R}_{3}{ }^{\prime}$} & \multirow[t]{2}{*}{$\mathrm{R}_{4}$} & \multicolumn{2}{|c|}{$\begin{array}{c}\text { Digitaria } \\
\text { adscendens }\end{array}$} & \multicolumn{2}{|c|}{$\begin{array}{l}\text { Alopecurus } \\
\text { aequalis }\end{array}$} & \multicolumn{2}{|c|}{$\begin{array}{c}\text { Poa } \\
\text { annua }\end{array}$} \\
\hline & & & & & 0.5 & 2.0 & 0.5 & 2.0 & 0.5 & $2.0^{\mathrm{a})}$ \\
\hline $\mathrm{Et}$ & $\mathrm{Et}$ & $\mathrm{H}$ & $\mathrm{H}$ & $\mathrm{H}$ & 5 & 10 & 6 & 10 & 0 & 3 \\
\hline $\mathrm{Et}$ & $\mathrm{Et}$ & $\mathrm{Me}$ & $\mathrm{H}$ & $\mathrm{H}$ & 6 & 10 & 6 & 10 & 0 & 3 \\
\hline $\mathrm{Et}$ & $\mathrm{Et}$ & $n-\operatorname{Pr}$ & $\mathrm{H}$ & $\mathrm{H}$ & 4 & 9 & 8 & 10 & 1 & 5 \\
\hline $\mathrm{Et}$ & $\mathrm{Et}$ & $i-\operatorname{Pr}$ & $\mathrm{H}$ & $\mathrm{H}$ & 10 & 10 & 8 & 10 & 1 & 4 \\
\hline $\mathrm{Et}$ & $\mathrm{Et}$ & $n$-Hex & $\mathrm{H}$ & $\mathrm{H}$ & 5 & 8 & 6 & 10 & 0 & 3 \\
\hline $\mathrm{Et}$ & $\mathrm{Et}$ & $\mathrm{C}_{6} \mathrm{H}_{5}$ & $\mathrm{H}$ & $\mathrm{H}$ & 8 & 10 & 9 & 10 & 6 & 8 \\
\hline $\mathrm{Et}$ & $\mathrm{Et}$ & $2-\mathrm{C}_{4} \mathrm{H}_{3} \mathrm{~S}$ & $\mathrm{H}$ & $\mathrm{H}$ & 9 & 10 & 9 & 10 & 5 & 9 \\
\hline $\mathrm{Et}$ & allyl & $\mathrm{Me}$ & $\mathrm{Me}$ & $\mathrm{H}$ & 9 & 10 & 9 & 10 & 7 & 10 \\
\hline$n-\operatorname{Pr}$ & allyl & $\mathrm{Me}$ & $\mathrm{Me}$ & $\mathrm{H}$ & 10 & 10 & 10 & 10 & 2 & 5 \\
\hline$n-\operatorname{Pr}$ & Propargyl & $\mathrm{Me}$ & $\mathrm{Me}$ & $\mathrm{H}$ & 10 & 10 & 10 & 10 & 3 & 6 \\
\hline $\mathrm{H}$ & allyl & $\mathrm{Me}$ & $\mathrm{Me}$ & $\mathrm{CO}_{2} \mathrm{Me}$ & 0 & 2 & 0 & 3 & 0 & 0 \\
\hline $\mathrm{Me}$ & allyl & $\mathrm{Me}$ & $\mathrm{Me}$ & $\mathrm{CO}_{2} \mathrm{Me}$ & 9 & 10 & 6 & 9 & 8 & 10 \\
\hline Et & allyl & $\mathrm{Me}$ & $\mathrm{Me}$ & $\mathrm{CO}_{2} \mathrm{Me}$ & 9 & 10 & 8 & 10 & 4 & 8 \\
\hline$i-\operatorname{Pr}$ & allyl & $\mathrm{Me}$ & $\mathrm{Me}$ & $\mathrm{CO}_{2} \mathrm{Me}$ & 1 & 2 & 1 & 3 & 0 & 1 \\
\hline$n-\mathrm{Bu}$ & allyl & $\mathrm{Me}$ & $\mathrm{Me}$ & $\mathrm{CO}_{2} \mathrm{Me}$ & 9 & 10 & 7 & 10 & 1 & 2 \\
\hline$n$-Pen & allyl & $\mathrm{Me}$ & $\mathrm{Me}$ & $\mathrm{CO}_{2} \mathrm{Me}$ & 1 & 3 & 3 & 5 & 1 & 2 \\
\hline$n-\operatorname{Pr}$ & $\mathrm{Me}$ & $\mathrm{Me}$ & $\mathrm{Me}$ & $\mathrm{CO}_{2} \mathrm{Me}$ & 7 & 10 & 8 & 10 & 0 & 1 \\
\hline$n-\operatorname{Pr}$ & Et & $\mathrm{Me}$ & $\mathrm{Me}$ & $\mathrm{CO}_{2} \mathrm{Me}$ & 8 & 10 & 7 & 9 & 0 & 1 \\
\hline$n-\operatorname{Pr}$ & $n-\operatorname{Pr}$ & $\mathrm{Me}$ & $\mathrm{Me}$ & $\mathrm{CO}_{2} \mathrm{Me}$ & 3 & 6 & 8 & 10 & 0 & 1 \\
\hline$n-\operatorname{Pr}$ & $n-\mathrm{Bu}$ & $\mathrm{Me}$ & $\mathrm{Me}$ & $\mathrm{CO}_{2} \mathrm{Me}$ & 4 & 6 & 8 & 10 & 0 & 1 \\
\hline$n-\operatorname{Pr}^{b)}$ & allyl & $\mathrm{Me}$ & $\mathrm{Me}$ & $\mathrm{CO}_{2} \mathrm{Me}$ & 10 & 10 & 10 & 10 & 3 & 8 \\
\hline$n-\operatorname{Pr}$ & allyl & $\mathrm{Me}$ & $\mathrm{Me}$ & $\mathrm{CO}_{2} \mathrm{Et}$ & 10 & 10 & 8 & 10 & 2 & 5 \\
\hline$n-\operatorname{Pr}$ & allyl & $\mathrm{Me}$ & $\mathrm{Me}$ & $\mathrm{CO}_{2}(n-\mathrm{Pr})$ & 9 & 10 & 8 & 10 & 1 & 6 \\
\hline$n-\operatorname{Pr}$ & allyl & $\mathrm{Me}$ & $\mathrm{Me}$ & $\mathrm{CO}_{2}(i-\mathrm{Pr})$ & 5 & 9 & 7 & 9 & 0 & 2 \\
\hline$n-\operatorname{Pr}$ & allyl & $\mathrm{Me}$ & $\mathrm{Me}$ & $\mathrm{CO}_{2}(n-\mathrm{Bu})$ & 6 & 9 & 7 & 10 & 1 & 3 \\
\hline
\end{tabular}

a) application rate $(\mathrm{kg} / \mathrm{ha})$.

b) alloxydim.

0 : no effect, 10: total control.

られた ${ }^{7)}$. 以上の研究より選抜された化合物中から, 製 剂面, 合成面等の各種の試験検討がなされセトキシジム (12)が選抜された.

アロキシジムは昭和 53 年に，セトキシジムは昭和 57 年にそれぞれ上市された。

\section{名称および性状}

\section{1.アロキシジム（普通名）}

化学名: メチル 3-(1-アリルオキシアミノブチリデ ン)-6,6-ジメチル-2,4-ジオキソシクロヘキサンカルボ
キシラートニナトリウム塩

性状：淡黄色結晶

融点： $185.5^{\circ} \mathrm{C}$

溶解度：(水) $>200 \mathrm{~g} / 100 \mathrm{ml}$, (有機溶媒) 難溶 製剂: $75 \%$ 水溶剤

商品名：クサガード, Fervin, Clout, Tritex

\section{2. セトキシジム（普通名）}

化学名：(士)-2-(1-エトキシイミノブチル)-5-[2-(エ チルチオ)プロピル]-3ーヒドロキシシクロヘキサ-2-エ , 
Table 5 Herbicidal activities of cyclohexanedione derivatives in post-emergence treatment.

\begin{tabular}{|c|c|c|c|c|}
\hline \multirow{2}{*}{$\mathrm{X}$} & \multirow{2}{*}{$\mathrm{R}_{1}$} & \multicolumn{2}{|c|}{ Digitaria adscendens } & \multirow{2}{*}{$\frac{\text { Sorghum halepense }}{\mathrm{a})}$} \\
\hline & & 0.25 & $0.5(\mathrm{~kg} / \mathrm{ha})$ & \\
\hline $\mathrm{Me}$ & Et & 1 & 2 & 一 \\
\hline $\operatorname{Pr}$ & $\operatorname{Pr}$ & 2 & 8 & 5 \\
\hline$i$-Pr & $\mathrm{Et}$ & 2 & 5 & 2 \\
\hline$i$-Bu & $\operatorname{Pr}$ & 0 & 4 & 1 \\
\hline$s-\mathrm{Bu}$ & $\operatorname{Pr}$ & 3 & 10 & 4 \\
\hline Hex & $\operatorname{Pr}$ & 1 & 5 & 1 \\
\hline$\triangleleft$ & $\operatorname{Pr}$ & 8 & 10 & 3 \\
\hline$\widehat{\mid H} \mid$ & $\operatorname{Pr}$ & 2 & 10 & 4 \\
\hline $\mathrm{C}_{2} \mathrm{H}_{4} \mathrm{I}$ & $\operatorname{Pr}$ & 0 & 2 & 0 \\
\hline COOMe & $\operatorname{Pr}$ & 0 & 7 & 2 \\
\hline $\mathrm{C}_{2} \mathrm{H}_{4} \mathrm{OMe}$ & $\operatorname{Pr}$ & 3 & 9 & 6 \\
\hline $\mathrm{C}_{2} \mathrm{H}_{4} \mathrm{OEt}$ & $\operatorname{Pr}$ & 2 & 9 & 4 \\
\hline $\mathrm{CH}_{2} \mathrm{O}-\langle\overline{\mathrm{O}}\rangle-\mathrm{Cl}$ & $\operatorname{Pr}$ & 3 & 7 & 2 \\
\hline $\mathrm{CH}_{2} \mathrm{SEt}$ & $\operatorname{Pr}$ & 10 & 10 & 7 \\
\hline $\mathrm{C}_{2} \mathrm{H}_{4} \mathrm{SMe}$ & $\operatorname{Pr}$ & 10 & 10 & 8 \\
\hline
\end{tabular}

a) seedling.

0 : no effect, 10: total control.

性状：油状液体

融点: 一

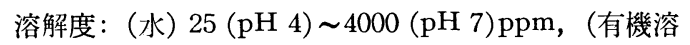
媒) 易溶

製剂: $20 \%$ 乳剂

商品名: ナブ, Fervinal, Poast, Checkmate, Expand

\section{合成 法}

セトキシジムの合成ルートにはいくつかの方法が考え られるが，Fig. 1 に示す合成ルートが工業的に有利であ ると考えられる. アロキシジムの合成法は割愛する.

\section{6-エチルチオ-3-ヘプテン-2-オン (V)の合成}

(I) と（II）を 3 級アミン触媒下に反応させることによ り容易に得られる(III) を用いてビニルケトン (V)を合 成した.ビニルケトンの合成法としては，アルドール縮 合による合成法 ${ }^{21)}$, クネーフェナーゲル反応による合成 法 $^{22)}$ ，ウィッティヒ反応による合成法 ${ }^{23)}$ な゙がある.し かしウィッティヒ法は原料が高価であるばかりでなく廃 棄物処理が困難であり，そのほかの方法は収率が低いな どのため工業的合成法としては得策とは考えられなかっ た.
一方，筆者らは $(\mathbf{V})$ の化合物がアルカリ，酸および熱 に不安定であることを見いだした．これらの条件を満足 させる反応基質および触媒などを探索し，アセト酢酸ナ トリウム塩(IV)とアルデヒド(III)を $N$-メチルヘキシル アミンの触媒下で $20 \sim 40^{\circ} \mathrm{C}$ 程度の温和な条件下で反応

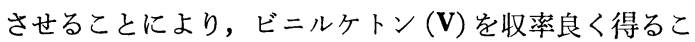
とができた。

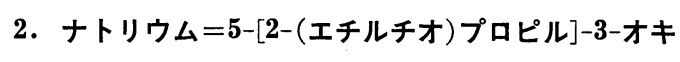
ソ-1-シクロヘキセン-1-オラート(VIII)の合成

2,4-ジオキソシクロヘキサン-1-カルボン酸エステル の合成法としてはマイケル反応が一般的である．この反 応を基に確立したアロキシジムの合成方法24)を利用して 目的とする (VIII) の中間体 (VII) を収率良く得た。この ようにして得られたエステル (VII) はカセイソーダ等の アルカリにより容易に加水分解し, その後塩酸等の酸に より脱炭酸し，目的とする(VIII)を収率良く得た。

3. 2-ブチリル-5-[2-(エチルチオ) プロピル]-3-ヒド ロキシ-2-シクロヘキセン-1-オン (XI) の合成

2-アシル-3-ヒドロキシ-2-シクロヘキセン-1-オン類 の合成法はすでに報告したごとく ${ }^{24)}$ ，既存の方法では低 収率であった。 
Table 6 Herbicidal activities of cyclohexanedione derivatives with sulfur-containing alkyl side chain.?<smiles>[R12]N=C([R1])C1=C(O)C([R3])C([R2])CC1=O</smiles>

\begin{tabular}{|c|c|c|c|c|c|c|c|c|}
\hline \multirow{3}{*}{ No. } & \multirow{3}{*}{$\mathrm{R}_{1}$} & \multirow{3}{*}{$\mathrm{R}_{2}$} & \multirow{3}{*}{$\mathrm{R}_{3}$} & \multirow{3}{*}{$\mathrm{R}_{4}$} & \multicolumn{4}{|c|}{ Post-emergence treatments } \\
\hline & & & & & \multicolumn{2}{|c|}{$\begin{array}{c}\text { Digitaria } \\
\text { adscendens }\end{array}$} & \multicolumn{2}{|c|}{$\begin{array}{l}\text { Avena } \\
\text { sativa }\end{array}$} \\
\hline & & & & & 0.125 & 0.5 & 0.125 & $0.5^{a)}$ \\
\hline 1 & $\operatorname{Pr}$ & allyl & $\mathrm{H}$ & $\mathrm{C}_{2} \mathrm{H}_{4} \mathrm{SMe}$ & 9.5 & 10 & 9 & 10 \\
\hline 2 & $\operatorname{Pr}$ & allyl & $\mathrm{H}$ & $\mathrm{C}_{2} \mathrm{H}_{4} \mathrm{SEt}$ & 7 & 10 & 4 & 10 \\
\hline 3 & $\operatorname{Pr}$ & allyl & $\mathrm{H}$ & $\mathrm{C}_{2} \mathrm{H}_{4} \mathrm{SPr}$ & 10 & 10 & 10 & 10 \\
\hline 4 & Et & Et & $\mathrm{H}$ & $\mathrm{C}_{2} \mathrm{H}_{4} \mathrm{SPr}$ & 9 & 10 & 10 & 10 \\
\hline 5 & $\operatorname{Pr}$ & allyl & $\mathrm{H}$ & $\mathrm{C}_{2} \mathrm{H}_{4} \mathrm{SCH}_{2}-\langle\overline{\mathrm{O}}\rangle$ & 5 & 10 & 10 & 10 \\
\hline 6 & Et & Et & $\mathrm{H}$ & $\mathrm{C}_{2} \mathrm{H}_{4} \mathrm{~S}-\langle\overline{\mathrm{O}}\rangle$ & 9 & 10 & 10 & 10 \\
\hline 7 & Et & Et & $\mathrm{H}$ & $\mathrm{C}_{2} \mathrm{H}_{4} \mathrm{~S}-\langle\overline{\overline{\mathrm{O}}}\rangle-\mathrm{Cl}$ & 10 & 10 & 10 & 10 \\
\hline 8 & Et & Et & $\mathrm{H}$ & $\begin{array}{c}\mathrm{C}_{2} \mathrm{H}_{4} \mathrm{~S}-\langle\overline{\bar{O}}\rangle-\mathrm{Me} \\
\mathrm{Cl}\end{array}$ & 10 & 10 & 8 & 10 \\
\hline 9 & Et & Et & $\mathrm{H}$ & $\mathrm{C}_{2} \mathrm{H}_{4} \mathrm{~S}-\langle\overline{\bar{O}}\rangle-\mathrm{Cl}$ & 4 & 7 & 5 & 9 \\
\hline 10 & $\operatorname{Pr}$ & allyl & $\mathrm{H}$ & $\mathrm{CH}(\mathrm{Me}) \mathrm{CH}_{2} \mathrm{SEt}$ & 9 & 10 & 7 & 10 \\
\hline 11 & $\operatorname{Pr}$ & allyl & $\mathrm{H}$ & $\mathrm{CH}_{2} \mathrm{CH}(\mathrm{Me}) \mathrm{SMe}$ & 10 & 10 & 8 & 10 \\
\hline 12 & $\operatorname{Pr}$ & Et & $\mathrm{H}$ & $\mathrm{CH}_{2} \mathrm{CH}(\mathrm{Me}) \mathrm{SEt}$ & 9 & 10 & 8 & 10 \\
\hline 13 & Et & $\mathrm{Et}$ & $\mathrm{H}$ & $\mathrm{CH}_{2} \mathrm{CH}(\mathrm{Me}) \mathrm{S}-\langle\overline{\mathrm{O}}\rangle-\mathrm{Cl}$ & 9.5 & 10 & 9 & 10 \\
\hline 14 & $\operatorname{Pr}$ & allyl & $\mathrm{H}$ & $\mathrm{CH}_{2} \mathrm{SEt}$ & 6 & 10 & 3 & 9.5 \\
\hline 15 & $\operatorname{Pr}$ & allyl & $\mathrm{H}$ & $\mathrm{CH}_{2} \mathrm{~S}-\langle\overline{\mathrm{O}}\rangle$ & 4 & 9 & 9.5 & 10 \\
\hline 16 & $\operatorname{Pr}$ & allyl & $\mathrm{H}$ & $\mathrm{CH}(\mathrm{Me}) \widehat{\mathrm{SMe}}$ & 9 & 10 & 10 & 10 \\
\hline 17 & $\operatorname{Pr}$ & allyl & $\mathrm{H}$ & $\mathrm{CH}(\mathrm{Et}) \mathrm{SEt}$ & 3 & 10 & 5 & 10 \\
\hline 18 & $\operatorname{Pr}$ & allyl & $\mathrm{H}$ & $\mathrm{C}(\mathrm{Me})_{2} \mathrm{SMe}$ & 9.5 & 10 & 10 & 10 \\
\hline 19 & $\operatorname{Pr}$ & allyl & $\mathrm{H}$ & $\mathrm{C}(\mathrm{Me}){ }_{2} \mathrm{SEt}$ & 9.5 & 10 & 10 & 10 \\
\hline 20 & $\mathrm{Et}$ & $\mathrm{Et}$ & $\mathrm{H}$ & $\mathrm{C}(\mathrm{Me})_{2} \mathrm{~S}-\langle\overline{\mathrm{O}}\rangle-\mathrm{Cl}$ & 6 & 10 & 7 & 10 \\
\hline 21 & $\operatorname{Pr}$ & ally1 & $\mathrm{H}$ & $\mathrm{C}_{2} \mathrm{H}_{4} \mathrm{SOMe}$ & 9 & 10 & 7 & 10 \\
\hline 22 & $\operatorname{Pr}$ & allyl & $\mathrm{H}$ & $\mathrm{C}_{2} \mathrm{H}_{4} \mathrm{SO}_{2} \mathrm{Me}$ & 7 & 10 & 8 & 10 \\
\hline 23 & Et & Et & $\mathrm{H}$ & $\mathrm{C}_{2} \mathrm{H}_{4} \mathrm{SO}-\langle\overline{\mathrm{O}}\rangle-\mathrm{Cl}$ & 9 & 10 & 10 & 10 \\
\hline 24 & $\mathrm{Et}$ & Et & $\mathrm{H}$ & $\mathrm{C}_{2} \mathrm{H}_{4} \mathrm{SO}_{2}-\langle\underline{\overline{\mathrm{O}}}\rangle-\mathrm{Cl}$ & 9 & 10 & 5 & 10 \\
\hline 25 & $\operatorname{Pr}$ & Et & $\mathrm{H}$ & $\mathrm{CH}_{2} \mathrm{CH}(\mathrm{Me}) \mathrm{SOEt}$ & 5 & 10 & 9 & 10 \\
\hline 26 & $\operatorname{Pr}$ & Et & $\mathrm{H}$ & $\mathrm{CH}_{2} \mathrm{CH}(\mathrm{Me}) \mathrm{SO}_{2} \mathrm{Et}$ & 1 & 6 & 4 & 10 \\
\hline 27 & $\mathrm{C}_{2} \mathrm{H}_{4} \mathrm{SEt}$ & allyl & $\mathrm{H}$ & $\mathrm{Me}, \mathrm{Me}$ & 0 & 0 & 0 & 0 \\
\hline 28 & Et & $\mathrm{CH}_{2} \mathrm{SMe}$ & $\mathrm{H}$ & $i-\operatorname{Pr}$ & 0 & 2 & 0 & 2 \\
\hline 29 & $\operatorname{Pr}$ & allyl & $\mathrm{CH}_{2} \mathrm{SPr}$ & $\mathrm{H}$ & 0 & 5 & 0 & 4 \\
\hline
\end{tabular}

a) application rate $(\mathrm{kg} / \mathrm{ha})$.

0 : no effect, 10: total control.

一方, 筆者らはジメドンからアシルジメドンを合成す る一連の研究に打いて, 中間体として $(\mathbf{X})$ の化合物を経 由することを見いだした，この知見を基に (VIII) から $(\mathbf{X})$ を合成するアシル化反応と $(\mathbf{X})$ から $(\mathbf{X I})$ を合成する 転位反応に分けて研究を行ない, アシル化反応について はピリジンのような求核触媒またはトリブチルアミンの ような相間移動触媒を少量使用することにより含水系で
もほぼ定量的に目的物を得た。また転位反応について は，4-N,N-ジメチルアミノピリジンのような超求核触 媒下で反応することにより容易に目的物 (XI) が得られ $る^{24)}$.

\section{4. セトキシジム $(\mathrm{XIII})$ の合成}

セトキシジムはアロキシジムで開発されたアリルオキ シアミンの合成法に準じて容易に合成されるエトキシア 


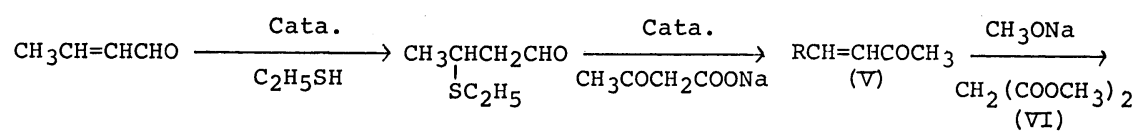

$\begin{array}{llll}\text { (I) } & \text { (II) } & \text { (III) }\end{array}$

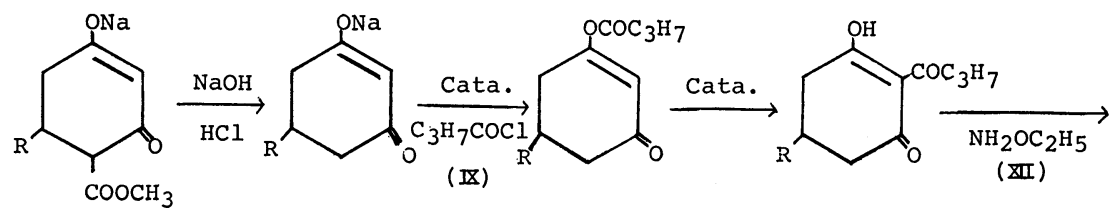

(VII)

(ㅍII)

(x)

(XI)<smiles></smiles>

(XIII)
$\mathrm{R}: \underset{\mathrm{SC}_{2} \mathrm{H}_{5}}{\mathrm{CH}_{3} \mathrm{CHCH}_{2}-}$

Fig. 1 Synthesis of sethoxydim.

Table 7 Herbicidal activities of sethoxydim on annual weeds in post-emergence treatment. ${ }^{8)}$

\begin{tabular}{|c|c|c|c|c|c|c|c|}
\hline \multirow{2}{*}{ Species } & \multirow{2}{*}{ Leaf stage } & \multicolumn{6}{|c|}{ Rate (kg/ha) } \\
\hline & & 0.05 & 0.1 & 0.2 & 0.4 & 2 & 4 \\
\hline Digitaria adscendens & $\left.4 \mathrm{~L}-\mathrm{t}^{\mathrm{a}}\right)$ & 5 & 9 & 10 & 10 & 10 & 10 \\
\hline Setaria vividis & $4 \mathrm{~L}-7 \mathrm{~L}$ & 3 & 7 & 9 & 10 & 10 & 10 \\
\hline Setaria faberi & $4 \mathrm{~L}-7 \mathrm{~L}$ & 2 & 6 & 9 & 10 & 10 & 10 \\
\hline Echinochloa crus-galli & $4 \mathrm{~L}-\mathrm{t}$ & 3 & 7 & 9 & 10 & 10 & 10 \\
\hline Alopecurus aequalis & $4 \mathrm{~L}-\mathrm{t}$ & 7 & 9 & 10 & 10 & 10 & 10 \\
\hline Avena fatua & $4 \mathrm{~L}-6 \mathrm{~L}$ & 3 & 8 & 10 & 10 & 10 & 10 \\
\hline Poa annua & $3 \mathrm{~L}-5 \mathrm{~L}$ & 0 & 0 & 0 & 0 & 7 & 10 \\
\hline Cyperus microiria & $2 \mathrm{~L}-3 \mathrm{~L}$ & 0 & 0 & 0 & 0 & 0 & 1 \\
\hline Chenopodium album & $2 \mathrm{~L}-4 \mathrm{~L}$ & 0 & 0 & 0 & 0 & 2 & 4 \\
\hline Amaranthus lividus & $2 \mathrm{~L}-3 \mathrm{~L}$ & 0 & 0 & 0 & 0 & 1 & 2 \\
\hline Stellaria media & $3 \mathrm{~L}-7 \mathrm{~L}$ & 0 & 0 & 0 & 0 & 2 & 2 \\
\hline Polygonum blumei & $2 \mathrm{~L}-4 \mathrm{~L}$ & 0 & 0 & 0 & 0 & 1 & 2 \\
\hline Xanthium strumarium & $2 \mathrm{~L}-3 \mathrm{~L}$ & 0 & 0 & 0 & 0 & 0 & 1 \\
\hline
\end{tabular}

a) $\mathrm{t}$ : tillering.

0: no effect, 10: total control.

ミン (XII) と化合物 $(\mathbf{X I})$ を $40 \sim 60^{\circ} \mathrm{C}$ の温和な条件下で＼cjkstart化合物であり，その除草特性も類似していることから， 反応させることにより, 高収率で得られる24). 本報では主としてセトキシジムについて述べる。

セトキシジムおよびアロキシジムの特性

\section{1. 除草特性}

代表的な一年生雑草に対する除草活性を Table 7 に アロキシジムとセトキシジムは化学構造的に類似した 示す.メヒシバ，エノコログサ，ヒエ等のイネ科雑草に 
Table 8 Tolerance of several crops to sethoxydim in post-emergence treatment. ${ }^{8)}$

\begin{tabular}{|c|c|c|c|c|}
\hline \multirow{2}{*}{ Crop $^{a)}$} & \multicolumn{4}{|c|}{ Rate $(\mathrm{kg} / \mathrm{ha})$} \\
\hline & 0.2 & 0.4 & 1.0 & 2.0 \\
\hline Soybean & 0 & 0 & 0 & 2 \\
\hline Tomato & 0 & 0 & 0 & 0 \\
\hline Lettuce & 0 & 0 & 0 & 0 \\
\hline Radish & 0 & 0 & 0 & 0 \\
\hline Sugar beet & 0 & 0 & 0 & 0 \\
\hline Cotton & 0 & 0 & 0 & 0 \\
\hline Onion & 0 & 0 & 0 & 0 \\
\hline Carrot & 0 & 0 & 0 & 0 \\
\hline Cucumber & 0 & 0 & 0 & 0 \\
\hline Cabbage & 0 & 0 & 0 & 0 \\
\hline Peanut & 0 & 0 & 0 & 3 \\
\hline Pea & 0 & 0 & 0 & 0 \\
\hline Wheat & 9 & 9 & 10 & 10 \\
\hline Barley & 9 & 10 & 10 & 10 \\
\hline Corn & 9 & 10 & 10 & 10 \\
\hline Rice & 9 & 10 & 10 & 10 \\
\hline
\end{tabular}

a) 2-4 leaf stage.

0 : no effect, 10: total control.

対し $0.2 \mathrm{~kg} / \mathrm{ha}$ 以上の薬量で完全枯死またはこれに近い 殺草効力を示した.ただし同じイネ科に属するスズメノ カタビラ (Poa annua)には $2 \mathrm{~kg} / \mathrm{ha}$ 以上の薬量を必要と し, 強い耐性を示した。一方, カヤッリグサおよびアカ ザ，イヌビユ等の広葉雑草には $4 \mathrm{~kg} / \mathrm{ha}$ でもわずかな作 用を示したにすぎなかった，次に作物に対する作用につ

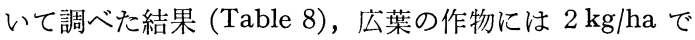
もほとんどの作物に影響がみられなかったが，小麦，ト ウモロコシ等の 4 種のイネ科作物には $0.4 \mathrm{~kg} / \mathrm{ha}$ 以上で
高い殺草作用を示した.このようにセトキシジムはイネ 科植物に対し非常に強い殺草作用を示すが，イネ科以外 の植物にはその作用はきわめて弱く, その間に大きな活 性差を示した.

セトキシジムは 3 種類の代表的多年生イネ科雑草に対 し $0.5 \mathrm{~kg} / \mathrm{ha}$ 以上で高い殺草作用を示し, とくにセイバ ンモロコシ (Sorghum halepense) の防除に $4 \mathrm{~kg} / \mathrm{ha}$ 以上 の薬量が必要とされるアロキシジムと比較し, 効力差が とくに顕著であった.シバムギには約 2 倍の効力差があ り, 泠涼な気候下で生育する雑草には一年生雑草の場合 と同様，セトキシジムとアロキシジムとの効力差は少な かった (Table 9).

次にセトキシジムのセイバンモロコシに対する処理適 期を調べた結果 (Fig. 2)，0.5 kg/ha の薬量で 2〜7葉期 までのいずれのステージの植物に対しても高い効力を示 した.しかしながら発生前の土塞処理では $1 \mathrm{~kg} / \mathrm{ha}$ の薬 量でも効力はきわめて弱く, 本剤は土壤処理より茎葉処 理で著しく高い効果が得られることがわかった．この傾 向は一年生雑草の場合も同様であった ${ }^{8)}$. 土塞処理で効 力が劣る原因として, セトキシジムは土塞中, とくに乾燥 土壤においては 1 週間でその効力のほとんどが失われ， 土䁃中の残効の短いことが考えられた ${ }^{8)}$. また Smith

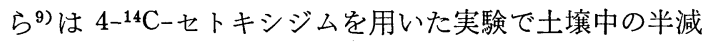
期が短いことを報告しており，土塞中で速やかに不活性 な化合物に分解されるものと考えられる。

以上よりセトキシジムは茎葉散布処理によりイネ科雑 草に卓効を示し, 散布時土壌中へ落ちた薬刜は速やかに 分解される薬剤であるといえる.

茎葉処理剤に必要な特性のひとつに耐雨性があげられ るので，セトキシジム散布直後の降雨により殺草効果が どのように変動するかについて検討した結果, 散布 1 時

Table 9 Herbicidal activities of sethoxydim and alloxydim-sodium on some perennial grasses in post-emergence treatment. ${ }^{8)}$

\begin{tabular}{|c|c|c|c|c|c|c|}
\hline \multirow{2}{*}{$\begin{array}{c}\text { Rate } \\
\text { (kg/ha) }\end{array}$} & \multicolumn{2}{|c|}{$\begin{array}{c}\text { Sorghum halepense } \\
\left.3-6 \mathrm{~L}^{\mathrm{a}}\right)\end{array}$} & \multicolumn{2}{|c|}{$\begin{array}{c}\text { Agropyron repense } \\
\qquad 3-4 \mathrm{~L}^{\mathrm{a})}\end{array}$} & \multicolumn{2}{|c|}{$\begin{array}{c}\text { Cynodon dactylon } \\
8-15 \mathrm{~cm}^{\mathrm{b})}\end{array}$} \\
\hline & Sethoxydim & $\begin{array}{l}\text { Alloxydim- } \\
\text { sodium }\end{array}$ & Sethoxydim & $\begin{array}{l}\text { Alloxydim- } \\
\text { sodium }\end{array}$ & Sethoxydim & $\begin{array}{l}\text { Alloxydim- } \\
\text { sodium }\end{array}$ \\
\hline 0.13 & 2 & 0 & 0 & 0 & 2 & - \\
\hline 0.25 & 7 & 0 & 2 & 0 & 6 & - \\
\hline 0.50 & 10 & 1 & 8 & 1 & 9 & - \\
\hline 1.00 & 10 & 2 & 10 & 8 & 10 & - \\
\hline 2.00 & 10 & 4 & 10 & 10 & 10 & - \\
\hline 4.00 & 10 & 9 & 10 & 10 & 10 & - \\
\hline
\end{tabular}

a) leaf stage. b) stolon length.

- : no applied, 0: no effect, 10: total control. 


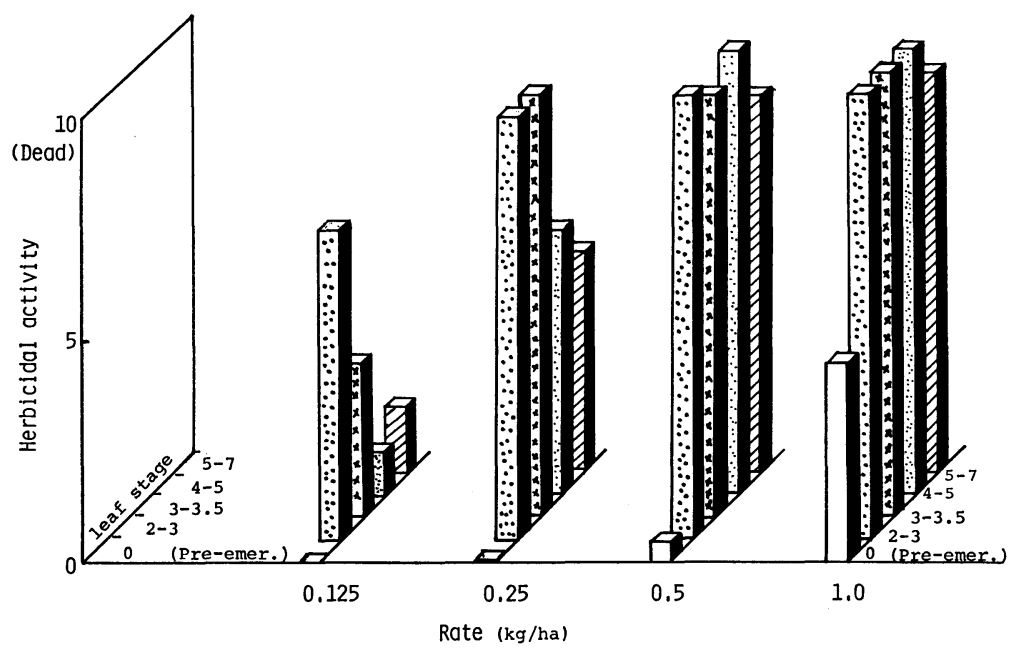

Fig. 2 Herbicidal activities of sethoxydim at different leaf stages of Sorghum halepense. 0 : no effect, 10: total control.

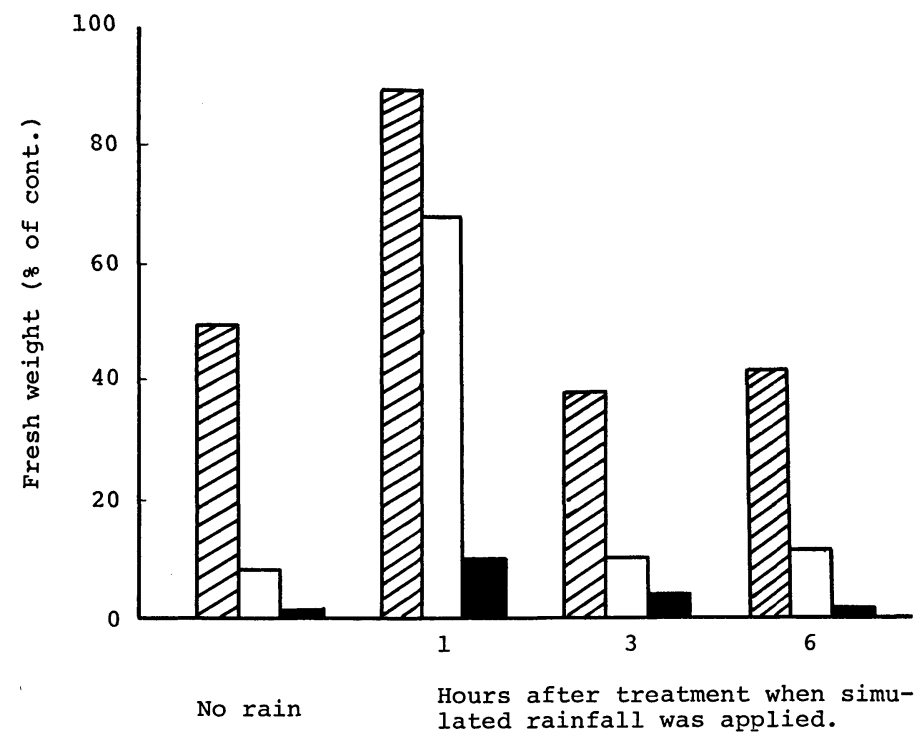

Fig. 3 Effects of simulated rainfall on the activity of sethoxydim against Setaria viridis. ${ }^{8)}$ : $0.05 \mathrm{~kg} / \mathrm{ha}, \square: 0.1 \mathrm{~kg} / \mathrm{ha}, \mathbf{\square}: 0.2 \mathrm{~kg} / \mathrm{ha}$.

間後の降雨では効力の低下が認められたが，3 時間以上 経過すればまったく降雨による影響はなかった。このこ とからセトキシジムは比較的短時間で植物体内へ取り込 まれる薬郕であると考兄られる (Fig. 3).

また一般に茎葉散布剂に望まれる特性として植物体内 の移行性の問題がある. 薬羭が雑草の茎葉部に散布され た際, 薬戍の接触した場所のみ枯死せしめる除草剤は, 散布条件によりその防除が不完全となる場合が多い。そ
こでセトキシジムについてその性質の有無を調べた。 3 葉期のメヒシバの第 2 葉の葉の先端部へマイクロシリン ジで $5 \mu 1$ 塗布し，その後の生育について検討した結果 (Fig. 4), 50 ppm で約 $90 \%$ を阻害し， 200 ppm (1 $\mu \mathrm{g}$ 量）でほぼ完全に植物全体を枯死させることから，七ト キシジムは植物体内を移行しやすい薬郕であることがわ かった．この移行性の大きいことが実際場面において散 布むらや雑草のステージの大きさに左右されることの少 


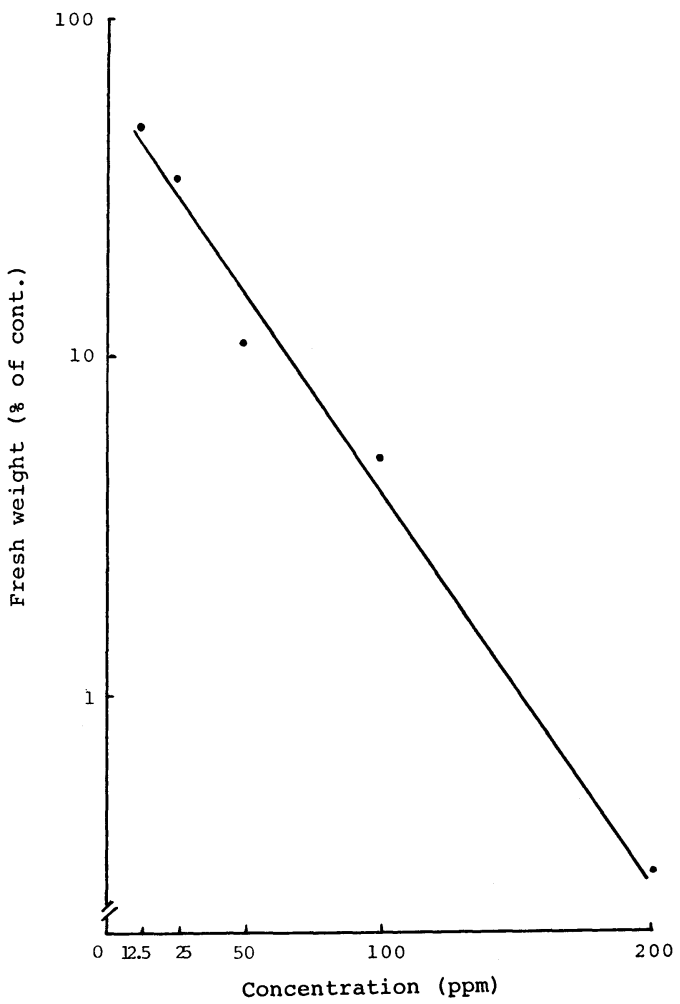

Fig. 4 Effect of sethoxydim on Digitaria adscendens at 3 leaf stage in $5 \mu \mathrm{l}$-droplet application.

The droplet was applied on a part of second leaf.

ない安定した効力が得られるひとつの理由と考えられ る.

\section{2. 選 択 性}

セトキシジムがイネ科雑草に特異的に作用を示すこと
は今まで述べたことで明らかであるが，前述したごとく イネ科植物の中でもセトキシジムに耐性を示す植物が存 在することがわかったので, イネ科植物内での感受性に ついて検討した ${ }^{10)}$. スズメノカタビラ以外に Festuca rubra (オオウシノケグサ) が耐性を示すことがわかった (Table 10). そこでこの 2 種について同属内での感受性 差について検討した結果, Poa annua (スズメノカタビ ラ）の場合, 同属である P. trivialis（オオスズメノカタ ビラ)と P. pratensis (ナガハグサ) はセトキシジムに感 受性であり，また F. rubva と同属の F. arundinacea (オニウシノケグサ), F. pratensis (ヒロ八ノウシノケグ サ）は感受性種であることがわかった (Fig. 5). とくに F. rubra と F. myuros は広葉植物と同等の強い耐性を示 した. 同じイネ科植物に属しながら広葉植物と同等の強 い耐性を示したことは注目すべきことと思われる。また 同じ属内においても大きな感受性差を示したことは大変 興味深い. スズメノカタビラについては，そのカルスに 対するアロキシジムの作用を報告している11). スズメノ カタビラから誘導したカルスは他のアロキシジムに感受 性のイネ科植物より誘導したカルスと同様にアロキシジ ムに高い感受性差を示した.このことからスズメノカタ ビラの耐性は植物体内への薬剂の取込みや体内での移行 に基づいていることが考えられた. Festuca 属の場合も これと同様の作用でセトキシジムに耐性を示すのかどう か検討した. 感受性種として F. arundinacea（オ二ウ シノケグサ), 耐性種としてF. rubra を用い, おのおの より誘導したカルスのセトキシジムに対する作用を調べ た結果, スズメノカタビラの場合と異なり明瞭な感受性 差が認められた ${ }^{12)}$. この違いを調べるために，4-14C-セ トキシジムの根からの取込みと代謝について検討した結 果, いずれの場合も差は認められなかった ${ }^{13)}$. このこと から F. rubra とF. arundinacea のセトキシジムに対

Table 10 Effects of sethoxydim and alloxydim-sodium on some grass weeds in post-emergence treatment.

\begin{tabular}{llcccccc}
\hline Herbicide & $\mathrm{kg} / \mathrm{ha}$ & $\begin{array}{c}\text { Digitaria } \\
\text { adscendens }\end{array}$ & $\begin{array}{c}\text { Avena } \\
\text { fatua }\end{array}$ & $\begin{array}{c}\text { Poa } \\
\text { annua }\end{array}$ & $\begin{array}{c}\text { Poa } \\
\text { trivialis }\end{array}$ & $\begin{array}{c}\text { Poa } \\
\text { pratensis }\end{array}$ & $\begin{array}{c}\text { Festuca } \\
\text { rubra }\end{array}$ \\
\hline \multirow{3}{*}{ Sethoxydim } & 0.125 & 10 & 4 & 0 & 10 & 10 & 0 \\
& 0.25 & 10 & 7 & 0 & 10 & 10 & 0 \\
& 0.5 & 10 & 10 & 0 & 10 & 10 & 0 \\
\hline \multirow{3}{*}{ Alloxydim-sodium } & 0.25 & 3 & 2 & 0 & 10 & 10 & 0 \\
& 0.5 & 10 & 6 & 0 & 10 & 10 & 0 \\
\end{tabular}

Leaf stage-D. adscendens: 3-4 L, A. fatua: 2.5-3 L, P. annua: 2-2.5 L, $P$. trivialis: $3.5-\mathrm{t}$, $P$. pratensis: $2.5-3 \mathrm{~L}, F$. rubra: 4-t (t: tillering stage). 


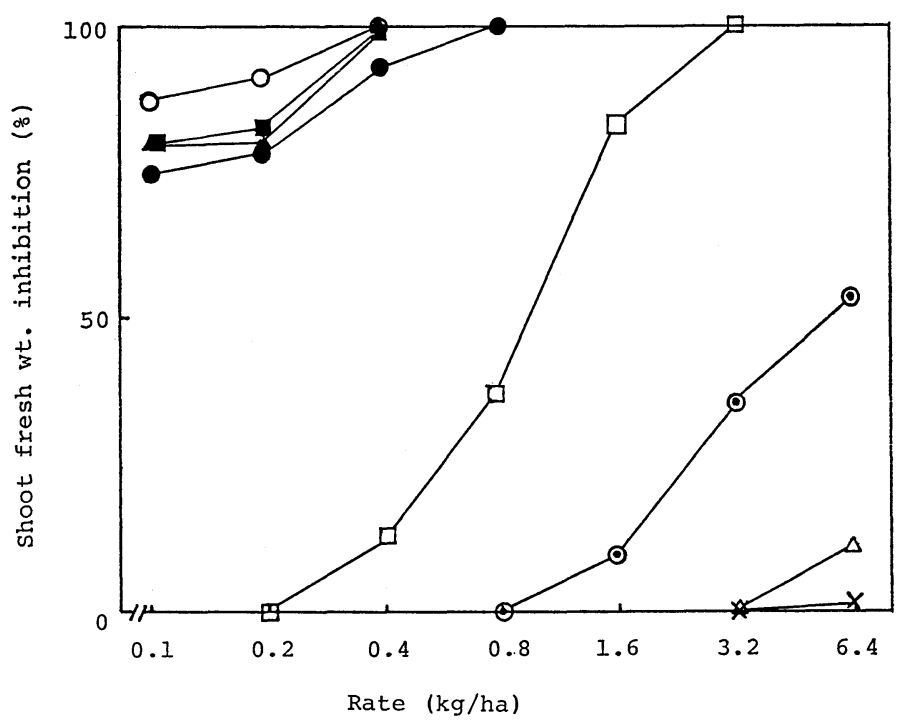

Fig. 5 Fresh weight of shoots of seedlings of five fescue and three bluegrass species treated with various rates of sethoxydim. ${ }^{10)}$

$\triangle$ : red fescue $(F . r u b r a), \times$ : rattail fescue (F.myuros), ๑: hard fescue (F. longifolia), ๑: meadow fescue (F. pratensis), $\bigcirc$ : tall fescue ( $F$. arundinacea), $\mathbf{\Delta}$ : rough-stalked meadowgrass (Poa trivialis), $\mathbf{\square}$ : Kentucky bluegrass (Poa pratensis), $\square$ : annual bluegrass (Poa annua).

する感受性の違いは他の耐性機構によることが示唆され た. セトキシジムに対する耐性の違いについてセイバン モロコシと大豆を用いた実験から，両者の代謝の違いを

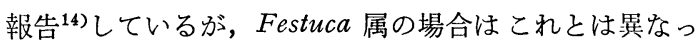
た作用機構で耐性に違いがでるのではないかと思われ る. 植物間の選択性の要因については, 解毒機構, 吸収 と移行の差で多くの場合説明されているが, CMPT に対 する小麦とメヒシバの感受性差はそれぞれが持つ生理的 な違いによることを示唆する報告もある ${ }^{15)}$. また difenzoquat の野性エンバクと大麦の感受性差は吸収, 移行, 代謝の違いからは説明できないという報告16)もあり， もっと本質的な違いにより選択性が生じる可能性を示唆 する例がある.

\section{3. 作用機作}

アロキシジム，七トキシジム両薬剤とも，作用特性， 殺草徵候の類似性から作用機作は同じと考えられる.両 薬剂とも，イネ科植物に散布されると，1〜2 日後には その植物の生育は停止するが，その時点では外見上植物 には何ら殺草徵候は観察されないので，一見した限りに おいては何ら影響を受けていないかにみられる。しかし エンバクを用いた実験で生長点部を縦断面に切断すると すでにその部分が褐変していることが観察され，さらに 顕微鏡観察の結果，処理後 12 時間目で植物の生長点部
における分裂像は認められなかった ${ }^{17)}$. またセトキシジ ムのトウモロコシの根端部に対する影響についても同様

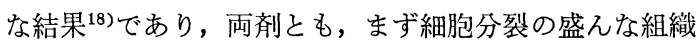
に作用することが考えられた，また一方，大豆から分離 した細胞を使った実験から原形質膜の脂質構成に影響す ること ${ }^{19)}$, さらに散布された葉に二次的な現象と推察し ているがアントシアンの蓄積 ${ }^{20)}$ 等の報告もあり, 生長点 部の細胞分裂の停止については, 今後さらに詳しい検討 がなされねばならない。

\section{おわりに}

茥葉散布でイネ科雑草にのみ活性を示すという今まで の除草剤にはまったくみられなかった特性を有するアロ キシジム，七トキシジムの発現は，それまでイネ科雑草 の防除に多大の労苦をしいられていた除草作業に一筋の 光明を与えたことと思われる．しかもとの防除が大変困 難であった多年生雑草の問題も同時に解決できたことは 作物栽培上きわめて意味のあることと思われる.さらに その選択性の大きさから散布時期の如何にかかわらず使 用できることは，実際に用いる人たちにとって安全で使 いやすい除草剂と思われる，今後とも，より高度な選択 性を有する安全な除草剤が望まれるのはもちろんのこ と, 環境污染による人畜に対する毒性の問題から，一層 
低薬量で使用できる薬戍が切望されてきている. 農薬開 発に携わる者として今後ともより優れた，より安全な農 薬を開発しなければならないことを痛感する次第であ る.

また一方, 両薬剤の開発過程で発見されたイネ科植物 内における感受性の違い等は今後詳しく研究することに よっては, 新しい選択性除草剤を生み出すひとつの手掛 かりになるかもしれないと思われる。

最後に本除草剂の開発に際し, 適切なるご助言をいた だいた宇都宮大学竹松教授にお礼を申し上げます。また 本剤は代謝, 残留, 毒性, 製剤等の多くの研究者の長年 にわたる多大の努力によって上市することができたもの であり，ここに心から感謝の意を表します.

\section{引用 文 献}

1) P. K. Pfeifter: Proc. Br. Crop Prot. Conf. Weeds, p. 1077, 1968

2) J. Rola: Proc. Br. Crop Prot. Conf. Weeds, p. 1083,1968

3) G. Gummesson: Proc. Br. Crop Prot. Conf. Weeds, p. 52, 1968

4) R. H. Goodwin \& C. Taves: Am. J. Bot. 37, 224 (1950)

5) B. M. Pollock, R. H. Goodwin \& S. Greene: Am. J. Bot. 41, 521 (1954)

6) I. Iwataki \& Y. Hirono: "Advances in Pesticide Science," ed. by H. Geissbühler, Part 2, Pergamon Press, Oxford, p. 235, 1979

7) I. Iwataki, M. Shibuya \& H. Ishikawa: "Pesticide Chemisty, Human Welfare and the Environment," ed. by J. Miyamoto, Vol. 1, Pergamon Press, Oxford, p. 151, 1983

8) H. Ishikawa, S. Yamada, H. Hosaka, T. Kawana, S. Okunuki \& K. Kohara: J. Pesticide Sci. 10, 187 (1985)

9) A. Smith \& A. Hsiao: Weed Res. 23, 253 (1983)

10) H. Hosaka, H. Inaba \& H. Ishikawa: Weed Sci. 32, 28 (1984)
11）廣野好彦, 石川尚雄：植物の化学調節 $\mathbf{1 6}, 137$ (1981)

12）未発表

13）未発表

14) B. A. Swisher \& F. T. Corbin: Weed Sci. 30, 640 (1982)

15）石塚皓造：雑草研究 28, 229 (1983)

16) M. P. Sharma, W. H. Vanden Borm, H. A. Friesen \& D. K. Mcbeath: Weed Sci. 24, 379 (1976)

17) H. Ishikawa, S. Okunui, T. Kawana \& Y. Hirono: J. Pesticide Sci. 5, 547 (1980)

18) H. Hosaka, H. Inaba, A. Satoh \& H. Ishikawa: Weed Sci. 32, 711 (1984)

19) K. K. Hatzios: Abstr. Weed Sci. Soc. Am. Meet., p. 117, 1982

20）井貝敬太郎, 上園孝雄, 大田英明, 浜田虔二, 田中 文隆：雑草研究 27, 121 (1982)

21) H. Rupe \& E. Hinterlach: Chem. Ber. 40, 4764 (1907)

22) A. T. Nielsen \& W. J. Houlihan: Org. Reactions 16, 87 (1968)

23) G. P. Schiemenz, J. Becker \& J. Stöckigt: Chem. Ber. 103, 2077 (1970)

24）佐脇幹夫：有機合成化学 39，408（1981） 